\title{
Financial inclusion: Household access to credit in Indonesia
}

\author{
B.Y. Gitaharie \& L. Soelistianingsih \\ Department of Economics, Faculty of Economics and Business, Universitas Indonesia, Depok, Indonesia \\ T. Djutaharta \\ Institute of Demography, Faculty of Economics and Business, Universitas Indonesia, Depok, Indonesia
}

\begin{abstract}
Financial inclusion has been an important issue recently, and has become one of the programmes of the Millennium Development Goals (MDG) of the United Nations (UN) to alleviate property all over the world. Indonesia has taken part in the programme. Financial inclusion aims to open access to formal financial services, especially bank services, to the poor. This access could leverage the poor's financial ability to provide capital for their business activities and improve their welfare with more affordable interest charged compared to non-financial institutions or informal moneylenders. The World Bank (2010) reports that only $21 \%$ of the Indonesian population have access to banks, which is considered a very low number. Using the National Economic Social Survey (SUSENAS) data of 2008 and 2012, this study identifies household profiles and analyses factors that determined households' access to loans from banks, non-bank institutions, and individual (informal) sources. The possibility for households to obtain loans is influenced by several factors such as demographics, including sex, socio-economic condition, education, and the effectiveness of government programmes on financial inclusion. The biggest constraint to obtaining bank loans is mainly the collateral. Most of the poor have no quality assets to pledge for bank collateral. The findings in this study could help the Indonesian government formulate more effective policies for poverty alleviation.
\end{abstract}

\section{INTRODUCTION}

Financial inclusion has become one important programme of the UN Millennium Development Goals (MDG) to open access to financial services. Financial inclusion aims to connect people with banks (Swamy, 2010) and provide them with more access to bank accounts, savings, credits, and other financial services. Band et al. (2012) stress that access to financial services by the poor and vulnerable groups is a prerequisite for poverty reduction. With broader access to financial services, these groups of people will have a larger opportunity to obtain more funds or capital to start up and run their businesses.

The World Bank (2010) reports that only $21 \%$ of Indonesia's population have access to banks and another $2 \%$ engage in formal non-bank financial services. In order to broaden access to financial services, the central bank of Indonesia, Bank Indonesia (BI), has promoted a programme called 'Tabunganku'. This programme introduces an inexpensive and safe banking product. 'Tabunganku' has the mandatory features of a very modest initial deposit of only IDR 20,000 (less than USD2), bearing no administrative fees, and paying returns based on customers' daily balances. To attract more customers, the central bank allows commercial banks that participate in the programme to provide customised/optional features on top of the mandatory features. Despite all the facilities, the programme has only attracted 3.2 million customers with total savings of IDR3.2 billion, or an average of IDR $1,000,000$ per customer as of March 2012. This figure is yet smaller compared to the total savings of IDR 2,800 billion and around 101 million customers. 
The National Economic Social Survey (SUSENAS) data, issued by Statistics Indonesia (Badan Pusat Statistik (BPS)), indicates that households obtain loans from formal (banks and non-bank) and informal (personal, relatives, neighbours, friends) institutions. Households with access to banks increased by $1.2 \%$ whereas access to non-bank institutions went up by $12.5 \%$ per year from $2008-2012$. What has restrained the access to banks?

The objectives of this research are to analyse households' determinant factors to obtain loans. To complement and enrich the results, the study also carries out in-depth interviews with several informants representing the banking regulator, banks, and business-owning households. The study also provides some recommendations to policymakers in improving access to banks.

\section{LITERATURE REVIEW}

\subsection{Financial sector and poverty alleviation nexus}

King and Levine (1993) and Levine $(1997,2005)$ have thoroughly demonstrated the positive relationship between the financial sector and economic growth, both in theoretical and empirical contexts. Through an efficient financial system, the financial sector channels funds to more productive uses and allocates risks to those who have the capabilities to bear risks (Demirguc-Kunt \& Honohan, 2008). In its development, the discussion on the financial sector-economic growth nexus has extended to more multidimensional issues, covering social and economic welfare. Honohan (2004) relates the financial development-economic growth with poverty and shows that financial depth is negatively correlated to headcount poverty rates. The discussion then goes deeper into whether economic growth and the intensive use of financial products-and-services have been pro-poor. Claessens (2006) points out that in many developing countries financial access has not reached all people. Beck and Demirguc-Kunt (2008) further state that financial exclusion may retard economic development. The poor's limited access to finance may contribute to impeding physical and human capital accumulation, which in turn will slow down economic growth and raise income inequality.

\subsection{Financial inclusion experience}

Access to finance, according to Band et al. (2012), is a necessary condition to lower the poverty rate. India has had a financial inclusion programme since 2004. The programme has been considered successful by having good coordination between the government and the central bank, and by taking into account the role of Indian women and human resource development (Bagli \& Dutta (2012); Band et al. (2012)). In order to reach out to more people and attract more bank customers, Indian commercial banks are allowed to work together with civil society groups, micro-institutions, and society organisations as business facilitators to act as intermediaries for rural people to access banks. The Indian government also provides campaign funds for the programme and recommends banks to open a branch for every 10,000 people. Previously, almost $60 \%$ of the population did not have bank accounts and almost $90 \%$ of the population did not have access to bank loans. Only in two years after the policy recommendation was put into effect, banks have opened their branches in 1,237 rural areas. The Reserve Bank of India has set a target of 600 million bank accounts in 2020 (Nalini \& Mariappan, 2012).

The financial sector in Uganda is not well developed yet and tends to be dualistic. Rural areas, mostly dominated by agricultural activities, have almost no access to financial services. In fact, credit services in rural areas are important as the agricultural sector is the main contributor to the Ugandan economy. Loans in rural Uganda mainly come from co-operatives, government programmes, relatives, local communities, and credit associations. Rural people rarely obtain loans from banks due to the distance of banks from rural areas. The demand for loans in Uganda (Mpuga, 2004) is found to positively correlate with demographic factors (education level, marital status, location where people live, age, and occupation in the 
household), interest rates, and distance to financial institutions. Mpuga also finds that young individuals tend to save and invest more than older individuals, and men tend to have control over assets. Individuals with higher income save more, and hence they have more assets to be pledged as collateral when they borrow money for business.

Likewise, around 40 million people in Indonesia do not have any access to financial services. BI (2012) identifies the problems of lack of access to financial services, which are due to geographical conditions, designs and patterns of services that often do not match the people's needs, and the information gap. On the other hand, many banks tend to provide loans to larger-scale entrepreneurs. Other factors such as level of education, legal issues, and self-exclusion are a few reasons that hold back the poor from bank access. BI has also launched campaign activities since 2008 to disseminate bank intermediary roles, products and services, benefits, risks and fees They all aim to increase Indonesia's marginal propensity to save and its domestic funds, and to promote a saving culture for Indonesians, particularly the productive poor.

\section{RESEARCH METHODS}

Two approaches are employed in this research - the analysis of quantitative data, and indepth interviews. The 2008 and 2012 SUSENAS data is employed. The use of the two-year data is to capture whether the implementation of the BI programme has a positive and significant effect on households' loans/credit obtainment.

Applying the multinomial logit regression (Cameron \& Trivedi (2005); Gujarati (2003)), the study investigates what factors determine the households' loans/credit obtainment. To complement the secondary data analysis, in-depth interviews (Jonker et al., 2011) are also conducted with several informants representing the regulator, financial institutions - both bank and non-bank - and productive poor households (micro-entrepreneurs).

Loans or credit in this study are defined as funds borrowed by households to run their business from various sources-banks, non-bank institutions, and non-formal personal sources. Credit obtained is determined by households' characteristics and socio-economic factors. Households' characteristics are represented by sex, age, education, location, marital status, and household size. Socio-economic factors include poverty status, employment status, employment sector, home ownership, and access to technology-fixed-line ownership, cell phone ownership, and computer ownership. This study also controls the implementation of public education programmes for banking by the use of year dummy. The multinomial logit model is as follows:

$$
\begin{aligned}
\log \left(\frac{p_{j}}{p_{0}}\right)= & \beta_{0}+\beta_{1} \text { sex }+\beta_{2} \text { age }+\beta_{3} \text { age } e^{2}+\beta_{4} \text { educ }+\beta_{5} \text { location }+\beta_{6} \text { marrital } \\
& +\beta_{7} \text { HHsize }+\beta_{8} \text { emplsect }+\beta_{9} \text { emplstatus }+\beta_{10} \text { houseown } \\
& +\beta_{11} \text { telown }+\beta_{12} \text { celltelown }+\beta_{13} \text { compown }+\beta_{14} \text { povstatus } \\
& +\beta_{15} \text { dcampaign }+\mathcal{\varepsilon}
\end{aligned}
$$

Equation 1 is estimated by maximum likelihood. The variable definition is described in Appendix 1 of this paper.

\section{RESULT AND DISCUSSION}

\subsection{Household profiles}

Most Indonesian households, based on 2008 and 2012 SUSENAS data, live in rural areas with low education, and work in agricultural and service sectors as own-account workers or as employers assisted by labour. Most households have real income of below IDR 750,000. The data indicate that $25 \%$ of the households have insufficient income to meet their daily needs. 
Figure 1 depicts how they make up for the insufficiency. Most of them borrow from relatives $(69 \%)$ and from neighbours/friends (54\%). Only a very small percentage of households come to formal institutions to close their deficit - co-operatives $(4 \%)$ and banks $(2 \%)$. This preliminary finding indicates that formal financial institutions are not the households' main option from whom to borrow money. Banks specifically seem detached from households.

Figures 2-4 display the distribution of households that get loans based on their poverty status. BPS classifies poverty status into poor, near poor, vulnerable poor, and non-poor. This study combines 'very poor' and 'poor' classifications into poor, and near poor and vulnerable poor into near poor (see Table A1 in Appendix 1). Figure 2 shows that nonpoor households have the largest opportunity to obtain loans from all sources, particularly banks. Near poor households obtain loans mostly from non-bank institutions and individuals (Figure 3). This group of households is vulnerable to degrade to poor, so the government provides more financial assistance to this group. Figure 4 displays the decreasing proportion of households that obtain loans from individuals (relatives, neighbours/friends), from $2.02 \%$ in 2008 to $1.89 \%$ in 2012, except for poor households. Poor households prefer borrowing from individuals to other sources because it is much quicker, easier in terms of not requiring legal documents, and requires no collateral to bepledged.

\subsection{Determinant factors of households' loans}

The estimation results (Table 1) indicate that households in urban areas are less likely to get loans from all sources relative to those in rural areas. This finding is interesting, as the fact

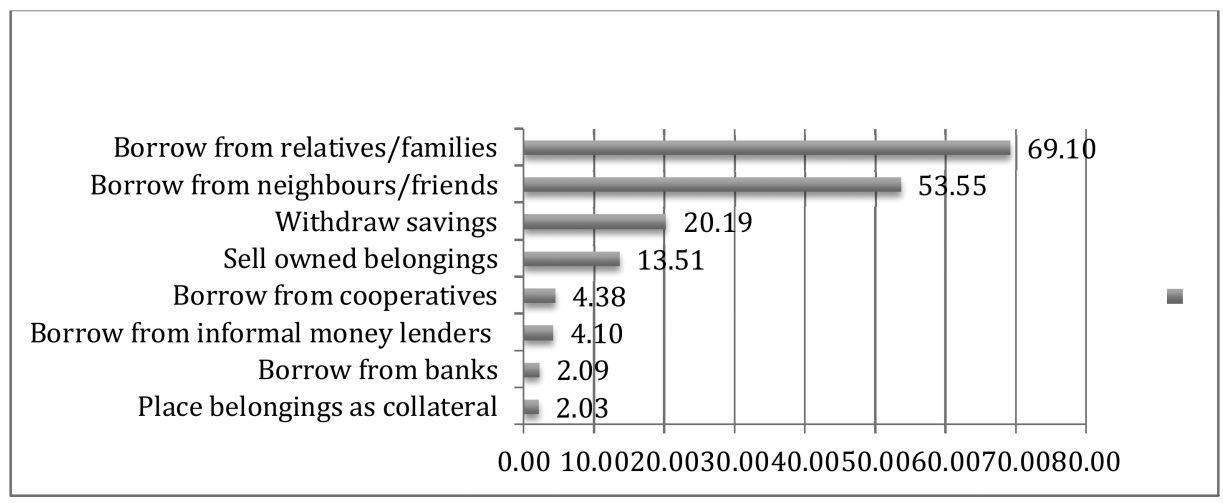

Figure 1. Source of funds of households in meeting their daily needs (\%), 2012.

Notes: Sample number $(\mathrm{n})=286,113$.

Source: Author's own estimation from 2012 SUSENAS data.

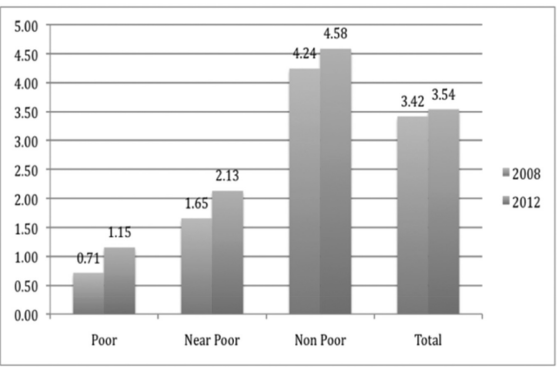

Figure 2. Distribution of households who obtain bank loans based on poverty status $(\%)$.

Source: Author's own estimation from 2008 and 2012 Susenas.

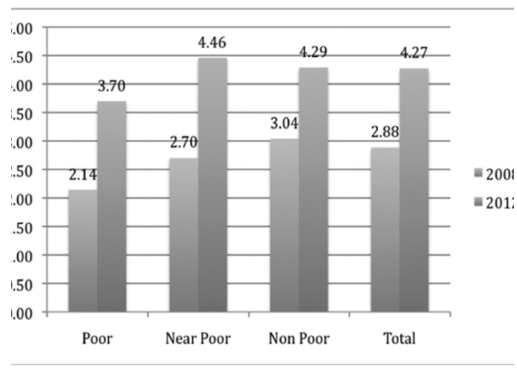

Figure 3. Distribution of households who obtain non-bank loans based on poverty status ( $\%)$. Source: Author's own estimation from 2008 and 2012 Susenas. 


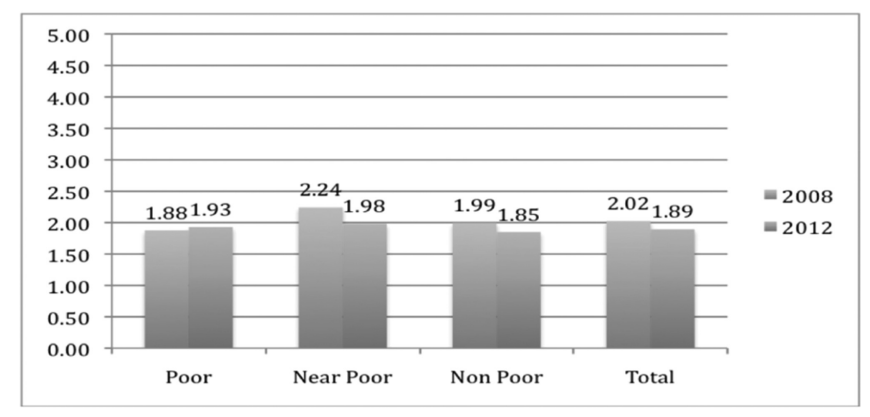

Figure 4. Distribution of households who obtain individual loans based on poverty status (\%). Source: Author's own estimation from 2008 and 2012 Susenas.

Table 1. Multinomial logistic regression results.

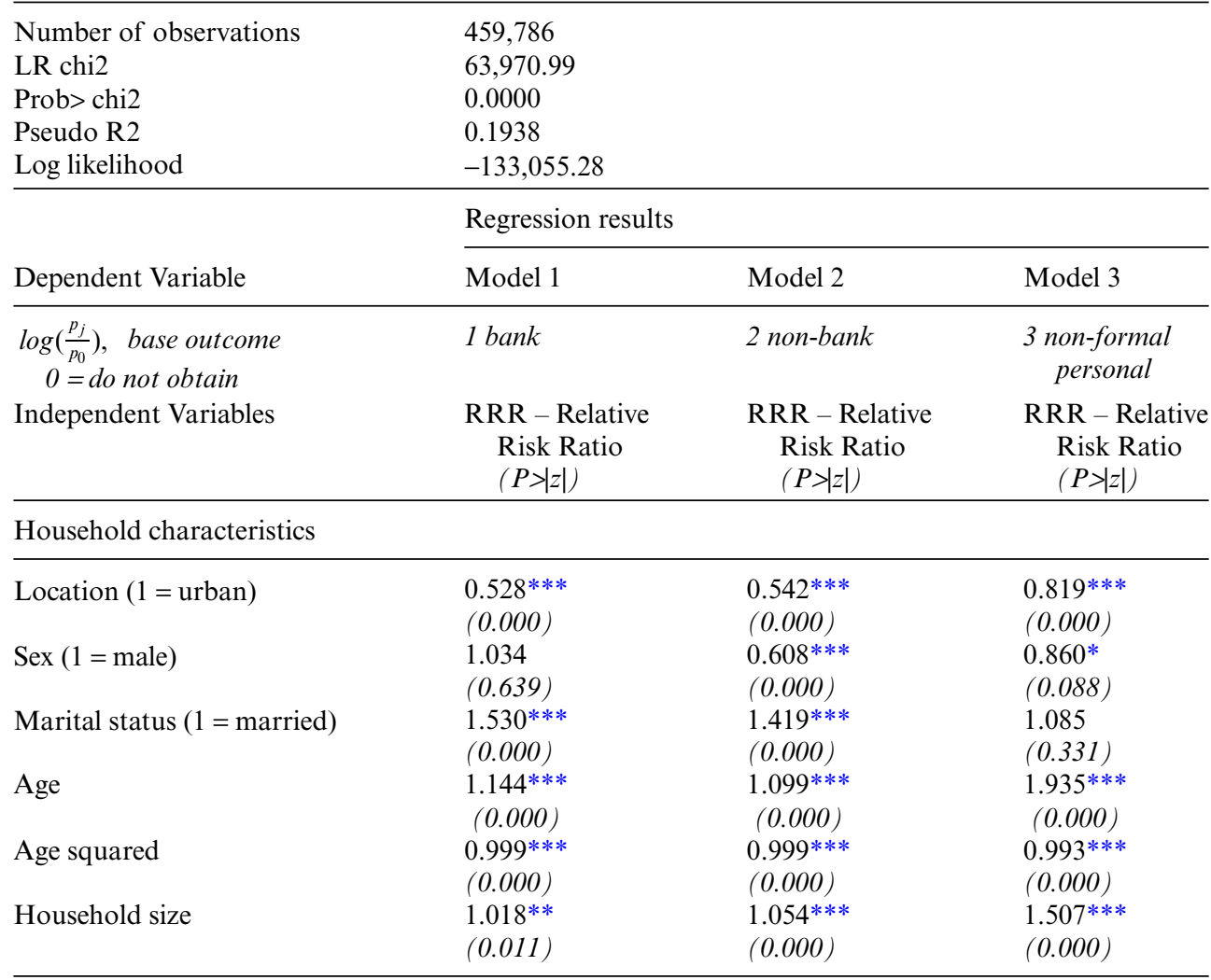

Education (reference category: did not graduate from elementary school)

\begin{tabular}{llll}
\hline Elementary education & $1.330^{* * *}$ & $1.122^{* * *}$ & 1.025 \\
& $(0.000)$ & $(0.000)$ & $(0.510)$ \\
Secondary education & $1.637^{* * *}$ & $1.359^{* * *}$ & $0.479^{* * *}$ \\
& $(0.000)$ & $(0.000)$ & $(0.000)$ \\
Tertiary education & $1.912^{* * *}$ & 0.976 & $2.093^{* * *}$ \\
& $(0.000)$ & $(0.525)$ & $(0.000)$ \\
College/university education & $2.790^{* * *}$ & 0.926 & 0.961 \\
& $(0.000)$ & $(0.215)$ & $(0.644)$ \\
\hline
\end{tabular}


Table 1. (Continued).

\begin{tabular}{|c|c|c|c|}
\hline \multicolumn{4}{|c|}{ Employment sector (reference category: other sector) } \\
\hline Agricultural sector & $\begin{array}{l}0.391 * * * \\
(0.000)\end{array}$ & $\begin{array}{l}0.764 * * \\
(0.001)\end{array}$ & $\begin{array}{l}0.882 \\
(0.308)\end{array}$ \\
\hline Mining sector & $\begin{array}{l}0.398 * * * \\
(0.000)\end{array}$ & $\begin{array}{l}0.895 \\
(0.325)\end{array}$ & $\begin{array}{l}0.949 \\
(0.755)\end{array}$ \\
\hline Manufacturing sector & $\left(0.812^{* *}\right.$ & $\begin{array}{l}1.08672 \\
(0.362)\end{array}$ & $\begin{array}{l}1.287^{*} \\
(0.055)\end{array}$ \\
\hline Service sector & $\begin{array}{l}0.814 * * \\
(0.000)\end{array}$ & $\begin{array}{l}0.93272 \\
(0.215)\end{array}$ & $\begin{array}{l}1.300^{* *} \\
(0.644)\end{array}$ \\
\hline \multicolumn{4}{|c|}{ Employment status (reference category: casual employee) } \\
\hline $\begin{array}{l}\text { Own-account worker or assisted } \\
\text { employer } \\
\text { Employee }\end{array}$ & $\begin{array}{l}1.776^{* * * *} \\
(0.000) \\
1.029 \\
(0.571)\end{array}$ & $\begin{array}{l}1.239 * * * \\
(0.000) \\
0.986 \\
(0.750)\end{array}$ & $\begin{array}{l}3.641 * * * \\
(0.000) \\
0.790 * * * \\
(0.000)\end{array}$ \\
\hline \multicolumn{4}{|l|}{ House, communication, and technology } \\
\hline $\begin{array}{l}\text { Home ownership }(1=\text { own home }) \\
\text { Fixed-line telephone ownership } \\
(1=\text { own fixed-line telephone }) \\
\text { Cellular telephone ownership } \\
(1=\text { own cell phone }) \\
\text { Computer ownership }(1=\text { own } \\
\text { computer })\end{array}$ & $\begin{array}{l}1.447 * * * \\
(0.000) \\
1.330 * * * \\
(0.000) \\
3.023 * * * \\
(0.000) \\
1.046 \\
(0.154)\end{array}$ & $\begin{array}{l}1.394 * * * \\
(0.000) \\
1.038 \\
(0.409) \\
1.407 * * * \\
(0.000) \\
0.531 * * * \\
(0.000)\end{array}$ & $\begin{array}{l}0.224 * * * \\
(0.000) \\
0.524 * * * \\
(0.000) \\
0.583^{* * *} \\
(0.000) \\
0.0716^{* * *} \\
(0.000)\end{array}$ \\
\hline \multicolumn{4}{|c|}{ Poverty status (reference category: poor) } \\
\hline Near poor & $\begin{array}{l}2.001 * * * \\
(0.000)\end{array}$ & $\begin{array}{l}1.598 * * * \\
(0.000)\end{array}$ & $\begin{array}{l}0.592 * * * \\
(0.000)\end{array}$ \\
\hline Non-poor & $\begin{array}{l}2.713 * * * \\
(0.000)\end{array}$ & $\begin{array}{l}1.446^{* * *} \\
(0.000)\end{array}$ & $\begin{array}{l}6.176 * * * \\
(0.000)\end{array}$ \\
\hline $\begin{array}{l}\text { Campaign program }(1=\text { year } 2012 \text {, } \\
\text { after program implementation })\end{array}$ & $\begin{array}{l}0.126^{* * * *} \\
(0.000)\end{array}$ & $\begin{array}{l}0.394 * * * \\
(0.000)\end{array}$ & $\begin{array}{l}1.512 * * * \\
(0.000)\end{array}$ \\
\hline Constant & $\begin{array}{l}0.0001 * * * \\
(0.000)\end{array}$ & $\begin{array}{l}0.002 * * * \\
(0.000)\end{array}$ & $\begin{array}{l}0.000^{* * * *} \\
(0.000)\end{array}$ \\
\hline
\end{tabular}

Source: Authors' own estimation.

Note: * significant at alpha $10 \%$, ** significant at alpha $5 \%$, and *** significant at alpha $1 \%$.

that it is harder to get loans in urban areas, particularly from banks, seems counter-intuitive. Inequality and urban poverty may explain the finding. Indonesia's Gini coefficient, that measures income inequality, slightly increased from 0.35 in 2007-2008, to 0.41 in 2011-2013, indicating that the equality gap between the haves and the poor has widened. Over two decades, the urban Gini coefficient in Indonesia has been larger than that of the rural (Badan Pusat Statistik, 2012, p. 417). BPS indicates that $11.6 \%$ people lived below the urban poverty line in 2008, and the figure declined to $8.4 \%$ in 2012. The urban poor lack access to basic services and also to business credit (World Bank, 2013).

Sex does not significantly affect the probability of households obtaining loans from banks. Women are more likely to get loans from non-banks and individuals, as banks often hesitate to lend women money because they lack the required collateral, as their property are not registered under their own names (World Bank, 2013). They prefer to go to lending-saving co-operatives, pawnshops, or participate in arisan (a gathering). It is estimated that $43 \%$ of 
formal Small and Medium-Sized Enterprises (SMEs) in Indonesia are women-owned (World Bank, 2013).

Being married indicates that couples engage in formal households and have a larger number of family members, hence a larger demand for finance. Married couples, that tend to own joint bank accounts and assets in the family, have a larger opportunity to get loans from banks and non-banks. Age positively and significantly affects the probability of households getting loans from all sources.

The probability of households getting loans from banks is larger for households with college/university degrees, while those with lower education level-secondary level - are more likely to get loans from non-bank institutions. The education level is less important for informal money lenders to provide loans. This finding may inform policymakers in choosing the means to attract bank customers - that is, policymakers should use easily-understood ways to communicate with unbanked people as they are mostly of lower level education.

Employment sectors are less likely to affect the probability of households obtaining loans from banks and non-bank institutions. This may be because they are not too confident to borrow from formal institutions due to the procedures and legal requirements. They, particularly those working in manufacturing and service sectors, are more likely to borrow from individuals as probably they need the loan immediately and not in a large amount. Households with own-account workers or assisted employers are more likely to have to get loans from banks, non-banks, and individuals, compared to those with an employment status as employees. Being an employee may provide a more fixed and regular income than being an own-account worker.

Home ownership provides a higher probability for households to get loans both from banks and non-bank institutions. Homes (ownership documents of them) can be placed as collateral for credit to cover risks for the loan providers. SUSENAS data (Badan Pusat Statistik, 2008 and 2012) indicate that $80 \%$ of households have their own homes. However, from the in-depth interviews with micro-entrepreneurs, they are not raring to place their houses as collateral as a home may be their only and most valuable asset.

Information may be accessed more easily nowadays via the use of telephones, both fixed lines and cell phones, and on-line computers. Through these media, information is retrieved faster and cheaper and can be accessed by more people. Banks use these media to promote and market their products. Customers' accessibility to these media becomes important. SUSENAS data (Badan Pusat Statistik, 2008 and 2012) shows that less than 10\% of households have fixed-line telephones, but nearly $80 \%$ of households have cell phones. From the multinomial logit estimation, it is found that telephone ownership - both fixed lines and cellular-provides a larger possibility for households to get loans from banks. Households with cell phone ownership in particular are three times more likely to get loans from banks. Households' familiarity with cell phones will facilitate the implementation of mobile payment services.

SUSENAS data (Badan Pusat Statistik, 2008 and 2012) also indicates that computer ownership, both laptops and desktops, doubled in 2012. Information nowadays is profoundly circulated in cyberspace. The increasing percentage of computer ownership indicates that households are getting more familiar with the use of computers. However, computer ownership is a less important consideration in obtaining loans.

Poverty status is an important consideration for formal institutions to provide loans. Both near poor and non-poor households have at least twice the probability of the poor in obtaining loans from banks and non-bank institutions. They have wider access to finance as they have more money to save and more assets to pledge as collateral if they want to borrow money from those formal institutions.

On the other hand, the poor are often excluded from formal financial institutions. Based on the in-depth interviews, the poor have insufficient income to save, have insufficient income to repay loans, have no valuable assets (except home ownership documents) to put as collateral if they want to borrow money, perceive that the documents to fill in are onerous, and often lack citizen identity cards (Kartu Tanda Penduduk (KTP)), whereas this identity card is a mandatory requirement to open savings accounts, and hence loans. 
To support their financial needs, some households run micro-scale businesses. This group of businessmen is longing for additional capital. It implies that they actually need access to banks. From the field, we find that some are banked micro-entrepreneurs; however, they use their accounts to simply keep revenues from their customers. They only practice simple banking transactions - save, transfer, and withdraw. Only a few of them have experience in borrowing money from banks. Some of them, who promptly repay their loans, face no difficulties, but some have had bad experiences with banks - particularly debt collectors - when they fail to repay the loans.

Some of the micro-entrepreneurs borrow money from individuals/informal moneylenders (rentenir in Indonesian language). In their opinion borrowing from rentenir is more practical, easier, and faster. Rentenir can provide immediate cash without collateral requirement. Rentenir come to the business sites to promote and market their lending services. They impose much higher borrowing rates. Some of the micro-entrepreneurs are trapped in huge debt to rentenir. However, due to the urgent need for cash to keep running the business, some are less concerned with how much they have to repay on their loans as long as the cash needed is immediately met. Rentenir occasionally prepare a less burdensome method of repayment. The repayment is made on a daily or weekly basis, whichever is more convenient for the micro-borrowers.

The market for such informal funding is still wide open, as long as the supply and demand exists. This may explain why the national campaign/movement to go to banks and to save, introduced by BI, is less likely to affect the probability of obtaining loans from formal institutions.

\section{CONCLUSION AND RECOMMENDATIONS}

Most Indonesian households, based on 2008 and 2012 SUSENAS data, live in rural areas with low education, and work in agricultural and service sectors as own-account workers or as employers assisted by labour. Most households have real income per capita of below IDR 750,000 and 25\% of them have insufficient income to meet their daily needs. Only a very small percentage of them come to formal institutions to make up for their deficit.

Based on the multinomial logit estimation, the probability of households obtaining loans from banks, non-bank institutions and individuals, relative to those who do not, is significantly affected by age, marital status, household size, employment status (ownaccount worker or assisted employer), home ownership, telephone ownership, and computer ownership. Households with college/university graduates are more likely to get loans from banks, whereas secondary and elementary school graduates are more likely to get loans from non-bank institutions and individuals respectively. In regard to poverty status, non-poor households have a higher probability to get loans from banks and individuals relative to the poor, whereas the near poor have a higher probability to get loans from non-bank institutions relative to the poor. The public campaign for banking is less likely to increase the probability of households getting loans from both banks and non-bank institutions. For comparison, further study may estimate the probability of households obtaining loans from banks and non-bank institutions, relative to those who obtain loans from individuals.

Based on the secondary and primary data findings, it is recommended for the central bank to urgently create lending programmes for the unbanked people with minimum collateral requirement as additional funds/capital are urgently required for them to run and keep their businesses. For that, the central bank should collaborate with commercial banks to make breakthroughs and create products that suit the poor's needs. Secondly, the issue of branchless banking, better known as mobile payment services, should be introduced and gradually implemented. A consideration found in the study is that nearly $80 \%$ of households in Indonesia own cell phones, so there is no doubt that they are technologically updated. 


\section{ACKNOWLEDGEMENT}

The authors would like to express their gratitute to Universitas Indonesia for providing the UI Research Grants 2013, high appreciation to Ms. Metri Sriwati for her administrative assistance and to Ms. Dwinda Andaninggar Hangonowati for her assistance in initial data processing.

\section{BIONOTE}

Beta Yulianita Gitaharie is currently a lecturer at Faculty of Economics and Business, Universitas Indonesia. Her research interests are in financial inclusion, economic development, monetary and macroeconomic issues.

Lana Soelistianingsih is currently a lecturer at Faculty of Economics and Business, Universitas Indonesia. Her research interestsare in financial and capital market.

Triasih Djutaharta is a PhD student at Faculty of Economics and Business, Universitas Indonesia and also a researcher at Lembaga Demografi, Faculty of Economics and Business, Universitas Indonesia. Her research interests are in public health, tobacco, and nutrition economics.

\section{REFERENCES}

Badan Pusat Statistik. (2007). Statistik Indonesia. Jakarta: BPS.

Badan Pusat Statistik. (2008). Statistik Indonesia. Jakarta: BPS.

Badan Pusat Statistik. (2009). Statistik Indonesia. Jakarta: BPS.

Badan Pusat Statistik. (2010). Statistik Indonesia. Jakarta: BPS.

Badan Pusat Statistik. (2011). Statistik Indonesia. Jakarta: BPS.

Badan Pusat Statistik. (2012). Statistik Indonesia. Jakarta: BPS.

Badan Pusat Statistik. (2008). Statistik Kesejahteraan Rakyat. Jakarta: BPS.

Badan Pusat Statistik. (2008). SUSENAS. Raw Data. Unpublished.

Badan Pusat Statistik. (2012). SUSENAS. Raw Data. Unpublished.

Bagli, S. \& Dutta, P. (2012). A study of financial inclusion in India. Radix of International Journal of Economics and Business Management, 1(8).

Band, G., Naidu, K. \& Mehadia, T. (2012). Opportunities and obstacles to financial inclusion. Arth Praband Journal of Economics and Management, 1(1).

Bank Indonesia. (2012). Booklet Perbankan 2012.

Beck, T. \& Demirguc-Kunt, A. (2008). Access to finance: An unfinished agenda. World Bank Economic Review, 22(3), 383-396. doi:10.1093/wber/lhn021.

Cameron, A.C. \& Trivedi, P.K. (2005). Micro econometrics: Methods and applications. London: Cambridge University Press.

Claessens, S. (2006). Access to financial services: A review of the issues and public policy objectives. World Bank Research Observer. doi:10.1093/wbro/lk1004.

Demirguc-Kunt, A., Beck, T. \& Honohan, P. (2008). Access to finance and development: theory and measurement. In F. Bourguignon \& M. Klein Finance for all: Policies and pitfalls in expanding access. World Bank, ISBN: 978-0-8213-7291-3.

Gujarati, D. (2003). Basic econometrics. International Edition. New York: McGraw Hill.

Honohan, P. (2004). Financial development, growth and poverty: How close are the links? World Bank Policy Research Working Paper 3203. http://econ.worldbank.org.

Jonker, J., Pennink, B.J.W. \& Wahyunil, S. (2011). Metodologipenelitian. Panduan Untuk Master Ph.D di bidang Manajemen. Jakarta: Salemba Empat.

King, R.G. \& Levine, R. (1993). Finance and growth: Schumpeter might be right. The Quarterly Journal of Economics, 108 (August), 717-738. doi:10.2307/2118406.

Levine, R. (1997). Financial development and economic growth: Views and agenda. Journal of Economic Literature, 35(2), 688-726. doi:10.1126/science.151.3712.867-a.

Levine, R. (2005). Chapter 12 finance and growth: Theory and evidence. Handbook of Economic Growth. doi:10.1016/S1574-0684(05)01012-9. 
Mpuga, P. (2004). Demand for credit in rural Uganda: Who cares for the peasant? Presented on Conference on Growth, Poverty Reduction and Human Development in Africa, Centre for the Study of African Economies.

Nalini, G.S. \& Mariappan, K. (2012). Role of banks in financial inclusion. The International Journal of Commerce and Behavioural Science, 1(4), 33-36.

Swamy, V. (2010). Bank-Based financial intermediation for financial inclusion and inclusive growth. Banks and Bank Systems, 5(4), 1-12.

World Bank. (2010). Improving access to financial services in Indonesia. Available from: http://www.bi.go. $\mathrm{id} / \mathrm{id} /$ perbankan/keuanganinklusif/berita/Documents/World $\% 20$ Bank $\% 20$ Report $\% 20-\% 20$ Improving $\% 20$ Access $\% 20$ to $\% 20$ Financial $\% 20$ Services $\% 20$ in $\% 20$ Indonesia.pdf accessed on April01, 2013.

World Bank. (2013). Indonesia: Urban poverty and program review. Available from: http://ifcextapps. ifc.org/ifcext $\% 5$ Cpressroom $\% 5$ Cifcpressroom.nsf $\% 5 C 0 \% 5$ C0CEFD2A433E3DE2685257FBD0026 B7FA accessed on October 01, 2016.

\section{APPENDIX 1}

Below is the description of variables used in the model (Equation 1).

\begin{tabular}{|c|c|c|}
\hline$j$ & $=$ & $\begin{array}{l}\text { source of credit with } p_{0}=\text { the probability of households do not obtain } \\
\text { credit (reference category), } p_{1}=\text { the probability of households obtain } \\
\text { credit from banks, } p_{2}=\text { the probability of households obtain credit from } \\
\text { non-bank institutions, } p_{3}=\text { the probability of households obtain non- } \\
\text { formal personal credit and i }\end{array}$ \\
\hline $\operatorname{sex}$ & $=$ & 1 if male, 2 if female (reference category) \\
\hline age & $=$ & Respondent's age of 15 or above \\
\hline educ & $=$ & $\begin{array}{l}\text { Education attainment of head of household measured from highest } \\
\text { diploma attainment, } 1 \text { if do not graduate from elementary school } \\
\text { (reference category), } 2 \text { if graduate from elementary school, } 3 \text { if graduate } \\
\text { from junior high school (secondary), } 4 \text { if graduate from high school, } 5 \text { if } \\
\text { graduate from college/university }\end{array}$ \\
\hline location & $=$ & 1 if urban areas, 2 if rural areas (reference category) \\
\hline marrital & $=$ & $\begin{array}{l}\text { Marital status, } 1 \text { if married, } 2 \text { if not married (never been married, life } \\
\text { divorced, death divorced) (reference category) }\end{array}$ \\
\hline HHsize & $=$ & Household size \\
\hline povstatus & $=$ & $\begin{array}{l}\text { Poverty status*, } 1 \text { if poor (reference category), } 2 \text { if near poor, } 3 \text { if non } \\
\text { poor }\end{array}$ \\
\hline emplsect & $=$ & $\begin{array}{l}\text { Employment sector in which respondents worked the last one week, } 1 \text { if } \\
\text { agricultural sector, } 2 \text { if mining/quarrying sector, } 3 \text { if manufacture sector, } \\
4 \text { if service sector, } 5 \text { if other sectors (reference category) }\end{array}$ \\
\hline emplstatus & $=$ & $\begin{array}{l}\text { Main employment status in the last one week, } 1 \text { if own account worker } \\
\text { or employer assisted by temporary/unpaid/permanent workers, } 2 \text { if } \\
\text { employee, } 3 \text { if casual employee (reference category) }\end{array}$ \\
\hline houseown & $=$ & House ownership, 1 if own, 2 if do not own house (reference category) \\
\hline telown & $=$ & $\begin{array}{l}\text { Fixed line communication ownership, } 1 \text { if own fixed line telephone, } 2 \text { if } \\
\text { do not own fixed line telephone (reference category) }\end{array}$ \\
\hline celltelown & $=$ & $\begin{array}{l}\text { Cellular phone ownership, } 1 \text { if own cell phone, } 2 \text { if do not own cell phone } \\
\text { (reference category) }\end{array}$ \\
\hline compown & $=$ & $\begin{array}{l}\text { Computer ownership, } 1 \text { if own computers (laptop/desktop), } 2 \text { if do not } \\
\text { own computers (laptop/desktop) (reference category) }\end{array}$ \\
\hline dcampain & $=$ & $\begin{array}{l}\text { Year of bank campaigns by BI, } 1 \text { if year is } 2008 \text { prior to the program } \\
\text { implementation (reference category), } 2 \text { if year is } 2012 \text { after the program } \\
\text { implementation }\end{array}$ \\
\hline
\end{tabular}

Note:*is explained below.

BPS definition of poverty status in this study is simplified into three categories onlypoor, near poor, and non-poor. BPS' very poor category is combined with poor and vulnerable poor with near poor. Table A1 summarizes the modified poverty status definition. 
Table A1. Definition of poverty status.

\begin{tabular}{|c|c|c|c|c|}
\hline \multirow[b]{2}{*}{ No. } & \multicolumn{2}{|c|}{ BPS definition } & \multicolumn{2}{|c|}{ Authors' simplified definition } \\
\hline & $\begin{array}{l}\text { Poverty } \\
\text { status }\end{array}$ & $\begin{array}{l}\text { Ranges of poverty } \\
\text { line }(\mathrm{PL})^{* *}\end{array}$ & $\begin{array}{l}\text { Poverty } \\
\text { status }\end{array}$ & Ranges of poverty line (PL) \\
\hline 1 & Very Poor & $\begin{array}{l}\text { expenditure per capita } \\
<0.8 \times \mathrm{PL}\end{array}$ & & \\
\hline 2 & Poor & $\begin{array}{l}0.8 \times \mathrm{PL} \leq \text { expenditure } \\
\text { per capita }<1.0 \times \mathrm{PL}\end{array}$ & Poor & $\begin{array}{l}0.8 \times \mathrm{PL}<\text { expenditure per capita } \\
<1.0 \times \mathrm{PL}\end{array}$ \\
\hline 3 & Near Poor & $\begin{array}{l}1.0 \times \mathrm{PL} \leq \text { expenditure } \\
\text { per capita }<1.2 \times \mathrm{PL}\end{array}$ & $\begin{array}{l}\text { Near } \\
\text { Poor }\end{array}$ & $\begin{array}{l}1.0 \times \mathrm{PL} \leq \text { expenditure per capita } \\
<1.6 \times \mathrm{PL}\end{array}$ \\
\hline 4 & $\begin{array}{l}\text { Vulnerable } \\
\text { Poor }\end{array}$ & $\begin{array}{l}1.2 \times \mathrm{PL} \leq \text { expenditure } \\
\text { per capita } \leq 1.6 \times \mathrm{PL}\end{array}$ & & \\
\hline 5 & Non Poor & $\begin{array}{l}\text { expenditure per capita } \\
>1.6 \times \mathrm{PL}\end{array}$ & $\begin{array}{l}\text { Non } \\
\text { Poor }\end{array}$ & expenditure per capita $>1.6 \times \mathrm{PL}$ \\
\hline
\end{tabular}

**The poverty line in this study is based on the provincial rural-urban areas.

Table A2. In-depth interview summaries.

\begin{tabular}{|c|c|c|c|c|c|c|}
\hline $\begin{array}{l}\text { Micro } \\
\text { business } \\
\text { type }\end{array}$ & $\begin{array}{l}\text { Sales per } \\
\text { month (in } \\
\text { million } \\
\text { IDR) }\end{array}$ & Bankable & $\begin{array}{l}\text { Source } \\
\text { of } \\
\text { loans }\end{array}$ & $\begin{array}{l}\text { Willingness to } \\
\text { borrow from banks } \\
\text { in the near future }\end{array}$ & $\begin{array}{l}\text { Constraints } \\
\text { to get bank } \\
\text { loans }\end{array}$ & $\begin{array}{l}\text { Knowledge } \\
\text { of } \\
\text { tabunganku } \\
\text { product }\end{array}$ \\
\hline (1) & (2) & (3) & (4) & (5) & (6) & (7) \\
\hline $\begin{array}{l}\text { 1. Traditional } \\
\text { Snack }\end{array}$ & 1.5 & Yes & NA & No & Never knows & No \\
\hline $\begin{array}{l}\text { 2. Catering } \\
\text { Services }\end{array}$ & $2.5-3$ & No & NA & $\begin{array}{l}\text { Very much wanted to } \\
\text { expand the business, } \\
\text { particularly to buy/ } \\
\text { rent land. }\end{array}$ & $\begin{array}{l}\text { Never borrows } \\
\text { from banks, } \\
\text { but knows } \\
\text { banks require } \\
\text { collateral }\end{array}$ & No \\
\hline 3. Lady’s Taylor & $3-3.5$ & Yes & $\begin{array}{l}\text { Cooperatives, } \\
\text { Bank }\end{array}$ & Wanted if necessary & No constraint & Yes \\
\hline 4. Convection K1 & 4 & Yes & Money lender & Very much wanted & No collateral & No \\
\hline 5. Convection $\mathrm{K} 2$ & $2-3$ (gross) & Yes & Bank & No information & No constraint & No \\
\hline 6. Convection K3 & 0.3 (gross) & Yes & $\begin{array}{l}\text { Family/ } \\
\text { Friends }\end{array}$ & No & No collateral & Yes \\
\hline $\begin{array}{l}\text { 7. Daily Utility } \\
\text { Shop } 1\end{array}$ & 6 & Yes & Bank & No & No constraint & Yes \\
\hline $\begin{array}{l}\text { 8. Daily Utility } \\
\text { Shop } 2\end{array}$ & 3.6 & No & NA & No & $\begin{array}{l}\text { Increasing } \\
\text { charges }\end{array}$ & No \\
\hline $\begin{array}{l}\text { 9. Furniture } \\
\text { Shop F1 }\end{array}$ & 50 & Yes & $\begin{array}{l}\text { Bank, } \\
\text { Cooperatives, } \\
\text { Money lender }\end{array}$ & No & $\begin{array}{l}\text { Increasing } \\
\text { charges }\end{array}$ & No \\
\hline $\begin{array}{l}\text { 10. Furniture } \\
\text { Shop F2 }\end{array}$ & 7 & Yes & Bank & $\begin{array}{l}\text { Willing to borrow in } \\
2014\end{array}$ & No constraint & Yes \\
\hline $\begin{array}{l}\text { 11. Agricultural } \\
\text { Shop A1 }\end{array}$ & $\begin{array}{l}60-90 \\
\text { (gross) }\end{array}$ & Yes & Bank & $\begin{array}{l}\text { No plan, still has } \\
\text { bank borrowing }\end{array}$ & No constraint & No \\
\hline $\begin{array}{l}\text { 12. Agricultural } \\
\text { Shop A2 }\end{array}$ & 1 (gross) & Yes & NA & No information & No collateral & No \\
\hline
\end{tabular}

Source: IDI results with micro enterprises. 